\title{
Erken Çocukluk Dönemi Bağlamında Geleceğin Öğretmenlerinin Cinsiyetçi Tutumları1,2
}

\author{
DOI: $10.26466 /$ opus.831271
}

*

\author{
İlayda Kimzan* - Arzu Arıkan** \\ * Arş. Gör. Dr., Muğla Sıtkı Koçman Üniversitesi, Eğitim Fakültesi, Muğla/Türkiye \\ E-Posta: ilayda.kimzan@gmail.com \\ ORCID: 0000-0002-0743-3162 \\ **Doç. Dr., Anadolu Üniversitesi, Eğitim Fakültesi, Eskişehir/Türkiye \\ E-Posta: arzuarikan@anadolu.edu.tr \\ ORCID: $\underline{0000-0002-4602-8901}$
}

\section{Öz}

Bu çalışmanın amacı erken çocukluk dönemindeki çocuklarla çalışacak öğretmen adaylarının cinsiyetçi tutumların çeşitli demografik değişkenler açısından betimlemektir. İlişkisel tarama deseninde yürütülen bu nicel araştırma kolay ulaşılabilir örnekleme ile ulaşılan 550 öğretmen adayı ile gerçekleştirilmiştir. Örnekleme dâhil olan öğretmen adaylar 2015-2016 eğitim öğretim yllında İç Anadolu Bölgesinde bir devlet üniversitesinin okul öncesi ve sinı öğretmenliği programlarında okuyanlar arasından belirlenmiştir. Veri toplama aracı olarak "Çelişik Duygulu Cinsiyetçilik Ölçeği" ve araştırmactların geliştirdiğgi genel bilgi formu kullanılmıştır. Veri analizinde betimsel istatistikler, $t$ testi, ANOVA ve Korelasyona başvurulmuştur. Araştırma sonucunda öğretmen adaylarının cinsiyet, yerleşim türü, anne eğitim durumu, gelir ve doğdukları şehirde hâkim olan siyasi görüşe göre düşmanca cinsiyetçi tutumlarında anlaml farklar olduğu görülmüştür. Öğretmen adaylarmın sinf, yaş, baba eğitim durumu, aile çalışma durumu ve herhangi bir seminer ya da çalı̧̧maya katılma durumlarına göre ise düşmanca cinsiyetçi tutumlarında anlaml bir fark yoktur. Korumace cinsiyetçi tutumlarda ise; sinıf, yaş ve ders/seminer/çalıştaya katılım durumuna göre anlamlı farklar vardır. Ö̆gretmen adaylarının korumacı cinsiyetçi tutumlarında yerleşim türüne, anne ve baba eğitim durumuna ve aile çalışma durumuna göre anlaml farklar görülmemiştir.

Anahtar Kelimeler: Erken Çocukluk, Okul Öncesi, Öğretmen Adayları, Cinsiyetçilik, Toplumsal Cinsiyet, Öğretmen Eğitimi.

\footnotetext{
${ }^{1}$ Bu çalışma ilk yazarın yüksek lisans tez araştırmasının bir bölümünden üretilmiştir. Kimzan, I. (2016). Erken çocukluk dönemi öğretmen adaylarının cinsiyetçilik ve çokkültürlü eğitime yönelik tutumları arasındaki ilişki (Yayımlanmamış Yüksek Lisans Tezi). Anadolu Üniversitesi, Eskişehir, Türkiye.

2 Bu araştırma Anadolu Üniversitesi BAP komisyonunca kabul edilen 1506 E526 no.lu proje kapsamında desteklenmiştir.
} 


\title{
Sexist Attitudes of Future Teachers in the Context of the Early Childhood Period
}

\begin{abstract}
This study aims to describe teacher candidates' sexist attitudes based on various demographic variables. It is a quantitative research conducted with 550 early childhood teacher candidates. The research was designed as a correlational study and the participants were selected using convenience sampling. They were studying at a state university's preschool and primary school teacher education program in the Central Anatolia Region during the 2015-2016 academic year. "Ambivalent Sexism Inventory" and a general information form were used as data collection instruments. For the data analysis, descriptive statistics, $t$ test, ANOVA, and correlation were utilized. According to the findings, there are significant differences in the candidates' hostile sexist attitudes based on their gender, type of residence, maternal educational status, income, and their hometown's dominant political view. On the other hand, there are no significant differences in the teacher candidates' hostile sexist attitudes based on their class, age, parents' education, family employment status, and participation in any seminar or study. Benevolent sexism is found to be significantly different based on teacher candidates' class, age, and participation in lecture/seminar/workshop. Finally, the teacher candidates' benevolent sexism does not significantly differ based on type of residence, maternal and paternal educational status, and family employment status.
\end{abstract}

Keywords: Early Childhood, Preschool, Preservice Teachers, Sexism, Gender, Teacher Education. 


\section{Giriş}

Bireyler arasındaki ilk farklılaşma biyolojik cinsiyet ile başlamaktadır. Cinsiyetin anne karnında 4. aydan itibaren belli olmasiyla birlikte bireylere bir kimlik atfedilmektedir. Bireylerin doğduğu anda sahip oldukları biyolojik cinsiyet toplum içerisinde çeşitli algılar ile şekillendirilmektedir. Bu durum birini ötekinden ayıran söylemler ve tutumları beraberinde getirmektedir. Çocukluktan yetişkinliğe uzanan süreçte ise cinsiyete yüklenen anlamların ortaya çıkardığı rollerin yaşatılması beklenmektedir. Cinsiyetin çok daha karmaşık bir yapı olduğunu ileri süren Chancer ve Watkins (2013), cinsiyetin tanımının basite alındığını ifade etmişlerdir. Bireyler, toplumun ve kültürün birer üyesi olduğu andan itibaren biyolojik cinsiyetin ötesinde farklılıkları vurgulayan toplumsal cinsiyet rolleri ile karşılaşmaktadırlar. Bu kapsamda kadın ve erkek özellikleri hakkında tutarlı biçimde kabul edilen yapılandırılmış inançlar cinsiyet kalıp yargıları olarak tanımlanmaktadır (Sears ve diğ., 1988). Bayhan da (2012) kadın ve erken arasındaki biyolojik farklılığa dikkat çekmekte, toplumsal cinsiyet kavramını da "kadın ya da erkek olmaya toplumun ve kültürün yüklediği anlamlar ve beklentiler" (s.153) şeklinde açıklamaktadır. Bu tanımlarda açıklandığı kadar soyut olmayan toplumsal cinsiyet rollerinin kadın ve erkek arasında somut eşitsizliklere zemin hazırladığı ifade edilebilir. Özellikle ataerkil değerlerin baskın olduğu kültürlerde, toplumsal cinsiyet rolleri daha keskin bir şekilde gündelik hayatın içinde olup ayrımcılık ve cinsiyetçilik gibi konuları da gündeme getirmektedir. Bu çalışmanın da konusunu oluşturan cinsiyetçiliğe, öğretmen eğitimi bağlamında 1şık tutularak okul öncesi ve ilkokul öğretmen adaylarının cinsiyetçi tutumları araştırılmıştır.

Cinsiyet kavramı, biyolojik anlamının dışında bireylere atfedilen roller ile toplumsal cinsiyet halini aldıktan sonra bireylere yapılan ayrımc1lıklar cinsiyetçiliği meydana getirmektedir. "Cinsiyetçilik, genel olarak kişinin cinsiyetine dayalı olarak yapılan ayrımcılıktır" (Sakallı Uğurlu, 2003, s.2). Bu kapsamda, kadınlara yönelik cinsiyetçilik, kadın oldukları için onlara yöneltilen olumsuz tutumlardır. Erkeklere yüklenen güç, statü ve kontrol erkekleri egemen hale getirmiştir. Kadınlar ise erkeklerin aksine güç ve statü içeren kamusal alanda değil özel alanda yer edinmeye zorlanmışlardır (Yuval-Davis, 2014). Toplumun kadını ezilen 
ve korunmaya muhtaç bir birey olarak tanımlayarak kadının bu konumunu pekiştirmesi de ne yazık ki cinsiyetçiliği yeniden inşa etmektedir. Glick ve Fiske' e (1996) göre cinsiyetçilik olgusu, "düşmanca ve korumacı" şeklinde iki farklı boyutta açıklanmaktadır. Olumsuz tutumları içeren düşmanca cinsiyetçilik, kadınlarla ilgili "yanlış ve esnek olmayan" genellemelere dayalıdır. Korumacı cinsiyetçilik ise kadının korunması ve yüceltilmesi gibi olumlu görünen tutumları içerse de kadını erkekten daha düşük seviyede gösteren ılımlı ama özünde kadına zarar veren önyargılarla ayırt edilmektedir. Diğer bir ifadeyle, korumacı cinsiyetçilikte yer bulan "kadının zayıf olduğu fikri aslında erkeğe hizmet etmektedir" (Sakallı-Uğurlu, 2003, s.8).

Kadınların her an karşı karşıya kaldığı cinsiyetçilik, mesleki, politik ve sosyal alanlarda ötekileştirilmelerine zemin hazırlamaktadır. Bunun örneklerini spordan iş hayatına, eğitimden günlük yaşantıya kadar her alanda görmek mümkündür. Özellikle kadınları olumsuz etkileyen bu durum, aslında sorunun nerede ve nasıl var olduğu, neden kaynaklandığı ve nasıl çözülmesi gerektiği ile ilgili araştırmaların yapılmasına da zemin hazırlamıştır. Bu açıdan, alanyazında cinsiyetçiliği farklı değişkenler açısından inceleyen çeşitli araştırmalar bulunmaktadır (Christopher ve Mull, 2006; Mikołajcz ve Pietrzak, 2014). Bu çalışmalarda yaş, eğitim, Katolik inancı, sosyal baskınlık, sağcı otoriterlik, Protestanlık etik değerleri, içsel dindarlık, dışsal dindarlık ve kutsal gerçekçilik gibi değişkenlere göre bireylerin cinsiyetçi tutumlarında anlamlı farklar olduğu ortaya konulmuştur. Örneğin, Mikolajczak ve Pietrzak (2014) dini inanç ile cinsiyetçilik arasındaki ilişkiye işaret etmişler ve dini değerlerin özellikle korumacı cinsiyetçiliği desteklediğini vurgulamışlardır. Benzer şekilde, Christopher ve Mull (2006) muhafazakâr ideoloji ile cinsiyetçilik; Burn ve Busso (2005) çelişik cinsiyetçi tutumlar ile din arasındaki ilişkiyi araştırmışlardır. Cowie, Greaves ve Sibley (2019) tarafından yapılan güncel bir araştırmada da cinsiyet ve cinsel kimliğe göre (eşcinsel / lezbiyen, biseksüel ve heteroseksüel bireyler) düşmanca ve korumacı cinsiyetçilik düzeylerinin farklılıklarına dikkat çekilmiştir. Bu çalışmada da erkeklerin kadınlara göre, heteroseksüellerin ise lezbiyen/gey ve biseksüellere kıyasla daha yüksek düşmanca ve korumacı cinsiyetçi tutumlar sergiledikleri belirlenmiştir. Kadınların toplumsal statüleri ve ayrımcıllğa uğramaları konusunda ise daha çok sosyolojik araştırmalar yapılmak- 
ta, şiddet gibi kavramlar ele alınmaktadır (Auspurg, Hinz ve Sauer, 2017; Sarı, 2017; Suğur ve Cangöz, 2016).

Cinsiyet odaklı çalışmalara eğitim alanında bakıldığında özellikle çocuk kitaplarının toplumsal cinsiyet rolleri açısından incelendiği görülmektedir (Akbar ve Azam, 2018; Balc1 ve Sel, 2017; Dilek, 2014; Fette, 2018; Kılıçoğlu, 2016). Toplumun gelişimine katkı sağlamada etkili olan kitapların kullanımı eğitim sürecinin de önemli bir parçasıdır. Bu açıdan eğitimde cinsiyetçilik ve toplumsal cinsiyet konulu çalışmaların son yıllarda arttığ1 ifade edilebilir (Coulter, 1995; Erden, 2004; Erdol Acar ve Gözütok, 2019; Haskan Avc1, Karababa ve Zencir, 2019; Koyuncu Şahin, Esen Çoban ve Korkmaz, 2018; McLaren, 2019; Öngören, 2019; Temiz ve Cin, 2017; Tezer Asan, 2010; Yılmaz, 2016). Bu bağlamda Erdol, Özen ve Toraman (2019) öğretmen adaylarının toplumsal cinsiyet eşitliğine ilişkin görüşlerini ortaya koymuşlar ve kadını erkeğe bağımlı gören ve erkeği üstün gören anlayışlara sahip olduklarını tespit etmişlerdir. Bu konuda cinsiyet ve branşlara göre farklı bulgulara ulaşmış araştırmalar da bulunmaktadır. Örneğin, Yazıcı ve Budak (2017) çalışmalarında kadın öğretmen adaylarının toplumsal cinsiyet farklılıklarına karşı tutumlarının erkeklere göre daha olumlu olduğunu belirtmişlerdir. Bayraktar ve Yağan Güder (2019) de okul öncesi öğretmen adaylarının toplumsal cinsiyet rollerine yönelik tutumlarının eşitlikçi olduğunu ortaya koymuşlardır. Ulusal alanyazının işaret ettiği gibi cinsiyet ve toplumsal cinsiyete ilişkin genel yönelimle çelişen, kadınlar ve okul öncesi öğretmen adayları lehine bulgular içeren araştırmalar olduğundan, bu alanın tartışmaya açık olduğu ve çok yönlü değerlendirmelere gereksinim duyulduğu gözlenmektedir. Bu bilimsel araştırmaların yanı sıra çocukların gelişimsel süreçlerinde çevrenin etkisi de cinsiyetçilik konusunda yapılacak çalışmaların eğitim açısından önemine işaret etmektedir.

Çocukların erken yaşlarda yakın çevresini aile ve okul ortamları oluşturmaktadır. Bu yakın çevre çocuklar için birincil kaynaklar olup bu kaynakların çocuklarda toplumsal cinsiyet rolleri ve kimliğe yönelik yarattığı algılar oldukça önemlidir. Çocuklar yaklaşık 3 yaşında diğerlerinin cinsiyetlerini doğru bir şekilde söyleyebilir ve 5 yaşından itibaren görünüş değişse de cinsiyetin değişmeyeceğini algılayabilir (Bee ve Boyd, 2009). Çocukların cinsiyet farklılıklarına yönelik olumlu ya da olumsuz tutumları da çevreye bağlı olarak gelişmektedir. Berk (2013) 
çocukların grup statüleri hakkındaki bilgileri sadece model alma yolu ile değil çevrelerindeki dolaylı mesajlar ile edindiklerine de değinmiştir. Spears Brown ve Bigler (2005) de bilişsel gelişim, durumsal faktörler ve bireysel farklılıkların çocuklarda kalıp yargılar ve ayrımcılık algılarının gelişimini etkilediğini vurgulamıştır. Ayrımcılık algısının gelişimi açısindan sosyalleşmenin de önemine değinerek ırk ve cinsiyete dayalı ayrımcılıklar için okul öncesi yıllara dikkat çekmişlerdir.

Çocuklar okul öncesi dönemi de kapsayan erken çocukluk yıllarında her açıdan hızlı bir değişim ve gelişim geçirirler. Bu gelişim sürecinde belirleyici olan pek çok çevresel etmene aile, TV, bilgisayar, kitaplar, akran ilişkileri ve öğretmenler örnek olarak verilebilir. Erken çocukluk döneminde çocukların aile dışında iletişim kurduğu, model aldığı ve etkileşime girdiği en önemli ve ilk yetişkinler okul öncesi ve ilkokul öğretmenleridir. Öğretmenlerin çocuklar üzerindeki bu etkileri dikkate alındığında öğretmen eğitimi sürecinden başlayarak, cinsiyet başta olmak üzere bireysel ve toplumsal farklılıkların her boyutunda olumlu tutumlara sahip olmaları; kendilerini eğitimde farklılıkların yönetimi konusunda geliştirmeleri ve insan hakları ve farklılıklara saygıyı öğretebilmeleri önemlidir. Bu açıdan bakıldığında öğretmen adaylarının gelecekte çocuklara olumlu rol modelleri olabilmeleri için öğretmen eğitimi süreci de şekillenmeli ve yüzyılın getirdiği gereklilikleri karşılar nitelikte olmalıdır. Öğretmen adaylarının alana çıkmadan önce geliştirdikleri tutumlar geleceğin öğretmenlerinin bu konudaki duruşlarını ortaya koyacaktır. Özellikle kadın öğretmen adaylarının çoğunluğu oluşturduğu okul öncesi eğitim ve sınıf eğitimi alanında, farklılıkların olumsuz bir noktası olan cinsiyetçilik konusunda, araştırmalar öğretmen eğitimi alanında önlemler alınmasına ve çözümler üretilmesine katkı sağlayacaktır. $\mathrm{Bu}$ çalışmanın amacı da erken çocukluk dönemi öğretmen adaylarının cinsiyetçi tutumlarının çeşitli değişkenler açısından betimlenmesidir. $\mathrm{Bu}$ kapsamda erken çocukluk dönemi öğretmen adaylarının cinsiyetçi tutumlarının ne düzeyde olduğu ve bu tutumlarda demografik özelliklere göre anlamlı bir fark olup olmadığı sorularına cevap aranmıştır. 


\section{Yöntem}

\section{Araştırma Deseni}

Bu çalışma ilişkisel tarama deseninde yürütülen ve farklılıkların çok boyutlu incelendiği kapsamlı bir tez araştırmasından üretilmiş olup bu makale kapsamında öğretmen adaylarının cinsiyetçi tutumlarının çeşitli değişkenler açısında betimlenerek karşılaştırılmasına odaklanılmıştır². Büyük örneklem grupları ile yapılan tarama araştırmaları, bireylerin ilgi, beceri, yetenek ve tutum gibi çeşitli özelliklerini betimleme amacı taşırlar (Büyüköztürk vd., 2008).

\section{Çalışma Grubu}

Çalışma grubunu bir devlet üniversitesinde okul öncesi ve sınıf öğretmenliği lisans programlarında eğitimlerine devam eden ve farklı sınıflardan kolay ulaşılabilir örnekleme yöntemi ile belirlenen öğretmen adayları oluşturmaktadır. Kolay ulaşılabilir örnekleme; evren içerisinde ulaşılması mümkün olan kişiler ile yürütülen araştırmalardır (Büyüköztürk ve diğ., 2008; Karasar, 1999). Bu araştırmanın evrenini İç Anadolu Bölgesi'nde bir devlet üniversitesinde Okul Öncesi Öğretmenliği ve Sınıf Öğretmenliği programında öğrenimlerine devam eden 1, 2, 3 ve 4. sınıflar oluşturmaktadır. İki programa devam eden öğrenci sayısı öğrenci işlerinden alınan listeye göre toplam 687 kişidir. Örnekleme sürecinde sınıf öğretmenliği ve okul öncesi öğretmenliği bölümlerinden çalışmaya katılan 550 öğretmen adayı çalışma grubunu oluşturmuştur. Okul öncesinden 254, sınıf öğretmenliğinden ise 296 öğretmen adayından veri toplanmıştır.

\section{Veri Toplama Araçları ve Tekniği}

Araştırma kapsamında öğretmen adaylarının cinsiyetçilik konusundaki tutumlarını ölçmek için Glick ve Fiske (1996) tarafından geliştirilen ve

\footnotetext{
${ }^{2}$ Bu tez araştırmasından üretilmiş diğer çalışma için, Kimzan, I., ve Arıkan, A. (2018). Erken çocukluk dönemi öğretmen adaylarının çokkültürlü eğitime yönelik tutumlarının incelenmesi. Inönü Üniversitesi Eğitim Fakültesi Dergisi, 19(3), 670-686. incelenebilir.
} 
Sakallı-Uğurlu (2002) tarafından Türkçe'ye uyarlanan "Çelişik Duygulu Cinsiyetçilik Ölçeği" kullanılmıştır. Demografik bilgiler için araştırmacılar tarafından hazırlanan genel bilgi formu kullanılmıştır. Türkçe uyarlaması yapılmış ölçek (Sakallı- Uğurlu, 2002) toplam 22 maddeden oluşmakla birlikte korumacı ve düşmancadan oluşan iki boyutta cinsiyetçiliği ölçmektedir. Ölçeğin iki faktörlü bir yapısı olup düşmanca ve korumacı cinsiyetçilik faktörleri için eşit sayıda madde (11) bulunmaktadır. Ölçeğin Cronbach Alfa katsayısı ,85 olarak bulunmuştur. Ayrıca korumacı cinsiyetçilik kendi içerisinde üç alt faktöre ayrılmaktadır. Bu alt faktörler; koruyucu ataerkillik, cinsiyetler arası tamamlayıcı farklılaştırma ve heteroseksüel yakınlıktır. Bu çalışmada ölçeğin düşmanca ve korumacı cinsiyetçilik boyutları temel alınmıştır.

Yapılan analizler bu çalışma kapsamında düşmanca cinsiyetçilik alt boyutunun Cronbach Alpha katsayısı , 85 ve korumacı cinsiyetçilik boyutunun ise, 79 olduğunu, ölçeğin tamamı için Cronbach Alpha değerinin ,85 olduğunu göstermiştir. Faktör analizine uygunluğunu test etmek için $\mathrm{KMO}$ ve Barlett's testleri yapılmıştır. Devamında doğrulayıcı faktör analizleri tamamlanmış ve uyum indekslerine bakıldığında (NFI=,944; NNFI=,965; IFI=,969; RFI=,937; CFI=,969; GFI=,933; AGFI=,917; REMSEA= ,046; $\mathrm{RMR}=$,117) değerlerin hepsinin kabul edilebilir veya mükemmel uyum gösterdiği görülmüştür (Seçer, 2013; Şimşek, 2007; Tabachnick ve Fidell, 2015).

Genel Bilgi Formu ile öğretmen adaylarına demografik özelliklerine yönelik temel sorular yöneltilmiştir. Toplam 12 adet soru ele alınmıştır. Bu sorular adayların cinsiyeti, lise türü, bölümü, sınıfı, bölümlerinden memnuniyeti, ebeveynlerinin eğitim durumu ve doğum yeri gibi farklı demografik özelliklere yönelik olarak hazırlanmıştır . Genel bilgi formunun dil açısından anlaşılır olup olmadığına yönelik olarak pilot uygulama yapılmıştır. Pilot uygulama için Sosyal Bilgiler Öğretmenliği lisans programına devam eden öğretmen adaylarına ulaşılmıştır. Gerekli düzenlemeler ile form son haline ulaşmıştır.

\section{Veri Toplama Süreci}

Veri toplama süreci başlamadan önce ölçek sahiplerinden ve Anadolu Üniversitesi Etik Kurulundan gerekli izinler alınmıştır. Araştırmacı veri- 
leri zorunlu ders saatlerinde ilgili öğretim elemanlarından destek alarak sınıf ortamında toplamıştır. Soru formu gönüllü öğrenciler tarafından ortalama 15 dakika içerisinde doldurulmuştur. Öğrencilerden araştırmaya gönüllü katıldıklarına dair yazılı izinleri de ölçekler ile toplanmış ve gizliliği sağlanmıştır. Veri toplama süreci 2015-2016 Güz döneminde final sınavları başlamadan önce ortalama 1,5 ayda tamamlanmıştır.

\section{Verilerin Analizi}

Veri analizi için ilk aşamada soru kitapçıkları tek tek incelenmiş ve tutarsız doldurulan ya da boş bırakılan kitapçıklar elenmiştir. Bu kontrollerin yapılmasından sonra dijital ortama veri girişi yapılmıştır. Parametrik testlerin yapılabilmesi için karşılanması gereken normal dağılım varsayımı test edilmiştir. Ölçeğin alt faktörlerine ve demografik değişkenlere göre normal dağılımın sağlandığı gözlenmiştir. Faktörler açısından birinci alt boyut olan düşmanca cinsiyetçilik için yapılan normallik testlerine bakıldığında histogram grafiği, Q-Q Plot grafikleri ve Box Plot grafiği istenilen özellikleri göstermiştir. İkinci aşamada çarpıklık ve basıklık değerleri kontrol edilmiş ve +1 ile -1 arasında değer aldığ 1 görülmüştür (çarpıklık= -,262, basıklık=,013). İkinci alt boyutu olan korumacı cinsiyetçilik faktörü Histogram grafiği, Q-Q Plot grafikleri ve Box Plot grafiği istenilen özellikleri göstermiştir. Çarpıklık değeri -,444 basıklık değeri ise ,034 şeklinde bulunmuştur. +1 ile -1 arasında olan bu değerlerin normallik şartlarını sağladığı görülmüştür (Huck, 2008). Veri analizinde normal dağılıma dayalı olarak parametrik testlere başvurulmuş; SPSS 21 paket programı ile betimleyici istatistikler, Pearson Korelasyon, t-testi ve ANOVA analizleri yapılmış ve etki büyüklükleri hesaplanmıştır.

\section{Bulgular}

$\mathrm{Bu}$ bölümde "Erken çocukluk dönemi öğretmen adaylarının cinsiyetçi tutumları nasıldır?" ve "Demografik özelliklerine göre erken çocukluk dönemi öğretmen adaylarının cinsiyetçi tutumlarında anlamlı bir fark var mıdır?" sorularının yanıtlarına yer verilmiştir.

Tablo 1'de öğretmen adaylarının ölçekten aldıkları puanlar ile ilgili betimsel istatistikler görülmektedir. 
Tablo 1. Öğretmen adaylarının cinsiyetçi tutumlarının betimsel istatistikleri

\begin{tabular}{llllll}
\hline & N & Min & X & Max & ss \\
\hline Toplam Çelişik Cinsiyetçilik & 550 & 1 & 3,67 & 5,27 &, 75566 \\
Düşmanca Cinsiyetçilik & 550 & 1 & 3,5059 & 6 &, 960 \\
Korumacı Cinsiyetçilik & 550 & 1 & 3,83 & 6 &, 87567 \\
Heteroseksüel Yakınlık & 550 & 1 & 3,95 & 6 & 1,15599 \\
Cinsiyetler Arası Tamamlayıcı & 550 & 1 & 3,85 & 6 & 1,11045 \\
Farklılaştırma & & 1 & 3,70 & 6 & 1,06599 \\
Koruyucu Ataerkillik & 500 & & &
\end{tabular}

Tablo 1'de görülen değerler ölçeğin genelinden alınan puanları göstermektedir. En düşük puan 1 olup en yüksek puan 5,27'dir. Tüm erken çocukluk dönemi öğretmenlerinin ise ortalaması 3,67'dir. Ölçekten alınan puanlar düştükçe öğretmen adaylarının daha az cinsiyetçi tutuma sahip oldukları, yükseldikçe ise daha yüksek cinsiyetçi tutumlara sahip oldukları ortaya çıkmaktadır. Bağımsız değişkenlere ait betimsel istatistik tablosu ise EK 1'de sunulmuştur.

Tablo 1'de görüldüğü üzere öğrencilerin genel olarak orta düzeyde düşmanca cinsiyetçi tutumlar sergilediği söylenebilir $(X=3,50)$. Korumac1 cinsiyetçilik alt boyutunda da ortalamanın biraz üstünde alınan puanlar görülmektedir $(X=3,83)$. Korumacı cinsiyetçilik faktörlerinin ortalama puanları; heteroseksüel yakınlık 3,95, cinsiyetler arası tamamlayıcı farklılaştırma 3,85, koruyucu ataerkillik ise 3,70 şeklindedir. Bu puanlar da öğrencilerin ortalamanın üzerinde cinsiyetçilik tutumlarına işaret etmektedir.

Kadınlar ve erkekler arasında cinsiyetçi tutumlar açısından anlamlı bir fark olup olmadığını test etmek için bağımsız örneklemler t-testi yapilmıştır (Tablo 2).

Yapılan t-testinde görüldüğü üzere erkeklerin düşmanca cinsiyetçi tutumları, kadınların düşmanca cinsiyetçi tutumlarına göre anlamlı düzeyde daha yüksektir. Fakat bu analizin eta kare değeri ise , 1 'dir. Dolay1sı ile bu istatistik küçük bir etkiyi ortaya koymaktadır. Korumacı cinsiyetçilik ve alt boyutu olan heteroseksüel yakınlıkta kadınlar ve erkekler arasında anlamlı bir fark yoktur. Cinsiyetler arası tamamlayıcı farklılaştırma alt boyutunda kadınların ortalaması $(X=3,99)$ erkeklerin ortalamasindan $(X=3,32)$ daha yüksek olup $p<, 000$ değeri ile anlamlı bir farklılık olduğu görülmektedir. Fakat eta kare değeri ,05 olup oldukça küçük bir 
etkiyi ifade etmektedir. Koruyucu ataerkillik alt boyutunda ise erkeklerin ve kadınların arasında erkekler lehine anlamlı bir fark olduğu görülmektedir $(\mathrm{p}<0.34)$. Sadece koruyucu ataerkillik boyutunda erkekler kadınlara göre daha fazla korumacı cinsiyetçi tutumlar sergilemektedir. Bu analizin eta kare değeri ,08 olup yine küçük bir etkiyi göstermektedir.

Tablo 2. Öğretmen adaylarının cinsiyetine göre düşmanca ve korumacı cinsiyetçilik t-testleri

\begin{tabular}{lcccccc}
\hline Grup & $\mathbf{n}$ & $\mathbf{X}$ & $\mathbf{S s}$ & $\mathbf{S d}$ & $\mathbf{t}$ & $\mathbf{p}<$ \\
\hline $\begin{array}{l}\text { Düşmanca Cinsiyetçilik } \\
\text { Kadın }\end{array}$ & 440 & 3,35 &, 90646 & & & \\
Erkek & 110 & 4,12 &, 92796 & 548 & $-7,904$ & \multirow{2}{*}{000} \\
\hline $\begin{array}{l}\text { Korumacı Cinsiyetçilik } \\
\text { Kadın }\end{array}$ & 440 & 3,86 &, 89690 & & & \\
Erkek & 110 & 3,71 &, 77642 & 548 & 1,814 & 0,71 \\
\hline $\begin{array}{l}\text { Heteroseksüel Yakınlık } \\
\text { Kadın }\end{array}$ & 440 & 3,98 & 1,14854 & & & \\
Erkek & 110 & 3,82 & 1,18160 & 548 & \multirow{2}{*}{1,327} & \multirow{2}{*}{, 185} \\
\hline $\begin{array}{l}\text { Cinsiyetler Arası Tamam- } \\
\text { layıcı Farklılıştırma }\end{array}$ & & & & & & \\
Kadın & 440 & 3,99 & 1,07474 & & & \\
Erkek & 110 & 3,32 & 1,09269 & 548 & 5,847 & \multirow{2}{*}{000} \\
\hline $\begin{array}{l}\text { Koruyucu Ataerkillik } \\
\text { Kadın }\end{array}$ & 440 & 3,65 & 1,08447 & & & \\
Erkek & 110 & 3,89 &, 96942 & 548 & $-2,128$ & \multirow{2}{*}{034} \\
\hline
\end{tabular}

Öğretmen adaylarının üniversitede devam ettikleri sınıflara göre yapılan ANOVA analizleri Tablo 3'te görülmektedir. Tablo 3'te görüldüğü üzere öğretmen adaylarının düşmanca cinsiyetçi tutumlarında, okudukları sınıfa göre anlamlı bir fark yoktur ( $\mathrm{p}<, 819)$. Korumacı cinsiyetçi tutumlarında ise okudukları sınıfa göre anlamlı bir fark vardır $(\mathrm{p}<, 000)$. Bu anlamlı farkın hangi gruplar arasında olduğunu tespit etmek adına varyans eşteşlik sonuçlarına bakılmış $(, 578)$ ve bu doğrultuda izleme testi olarak Scheffe testi yapılmıştır. Sonuçlara göre 4 . Sınıfa devam eden öğretmen adaylarının aldığı puanlar ile diğer sinıflara devam eden öğretmen adaylarının ortalama puanları arasında anlamlı bir fark vardır.

Bu durumda ortalama puanlar açısından 4. Sınıfa devam eden öğretmen adaylarının 1, 2 ve 3. Sınıfa devam eden öğretmen adaylarına göre anlamlı bir şekilde daha az korumacı cinsiyetçi tutuma sahip oldukları 
görülmektedir. Bu analizin eta kare değeri hesaplandığında ,04 ile oldukça küçük bir etki değerinin olduğu görülmektedir.

Tablo 3. Öğretmen adaylarııın sınıflarına göre cinsiyetçi tutumları ANOVA

\begin{tabular}{|c|c|c|c|c|c|c|}
\hline $\begin{array}{l}\text { Varyansın Kaynağı Düş- } \\
\text { manca Cinsiyetçilik }\end{array}$ & KT & Sd & КО & $\mathbf{F}$ & $\mathrm{p}<$ & Fark \\
\hline Gruplararası & 859 & 3 & 286 & & & \\
\hline Gruplariçi & 505,534 & 546 & ,926 & ,309 & 819 & - \\
\hline Toplam & 506,393 & 549 & & & & \\
\hline $\begin{array}{l}\text { Varyansın Kaynağı Koru- } \\
\text { macı Cinsiyetçilik }\end{array}$ & KT & Sd & KO & $\mathbf{F}$ & $\mathrm{p}<$ & Fark \\
\hline Gruplararası & 15,884 & 3 & 5,295 & & & $1-4$ \\
\hline Gruplariçi & 405,085 & 546 & ,742 & 7,136 & ,000 & $2-4$ \\
\hline Toplam & 420,969 & 549 & & & & $3-4$ \\
\hline
\end{tabular}

Öğretmen adaylarının cinsiyetçi tutumları ve yaşları arasında bir ilişki olup olmadığını görmek için Pearson Korelasyon Analizi yapılmıştır (Tablo 4).

Tablo 4. Öğretmen adaylarının yaşları ve cinsiyetçi tutumları arasındaki ilişki

\begin{tabular}{llll}
\hline $\mathbf{n}=550$ & Yaş & $\begin{array}{l}\text { Düşmanca } \\
\text { Cinsiyetçilik }\end{array}$ & $\begin{array}{l}\text { Korumaci Cinsiyet- } \\
\text { çilik }\end{array}$ \\
\cline { 2 - 4 } Yaş & - &,- 017 &,$- 134^{* *}$ \\
Düşmanca Cinsiyetçilik & & - &, $354^{* *}$ \\
\hline
\end{tabular}

**iliş̧ki, 01 düzeyinde anlamlıdır.

Yapılan analiz sonuçlarında görüldügü üzere yaş ve korumacı cinsiyetçilik arasında negatif yönde anlamlı bir ilişki görülmektedir. Dolayısı ile yaş arttıkça korumacı cinsiyetçi tutumlarda azalma söz konusudur. Fakat düşmanca cinsiyetçilik ile yaş arasında anlamlı bir ilişki yoktur.

Öğretmen adaylarının doğdukları yerleşim türlerine göre düşmanca ve korumacı cinsiyetçi tutumları konusunda yapılan ANOVA analizleri ise Tablo 5 'te özetlenmiştir.

Öğretmen adaylarının doğdukları yerleşim türü değişkeni 3 grup halinde ele alınmıştır. Bu gruplardan ilki köy/belde/kasaba (1), ikincisi ilçe (2) ve üçüncüsü il/merkez ilçe (3) olarak belirlenmiştir. Elde edilen sonuçlar doğrultusunda varyans eşteşliği sağlanmış ve ANOVA tabloları incelenmiştir. Analiz sonuçlarına göre öğretmen adaylarının düşmanca cinsiyetçi tutumlarında yerleşim türlerine göre anlamlı bir farklılık var- 
dır $(\mathrm{p}<, 006)$ Scheffe izleme testi sonuçlarına göre ise İl/Merkez ilçe ile İlçe arasında oluşan ortalama farkının anlamlı olduğu tespit edilmiştir. İlçede doğan öğretmen adaylarının il ya da merkez ilçede doğan öğretmen adaylarından anlamlı bir şekilde daha yüksek düşmanca cinsiyetçi tutumlar gösterdikleri görülmektedir.

Tablo 5. Öğretmen adaylarının doğduklarn yerleşim türlerine göre cinsiyetçi tutumlarn ANOVA

\begin{tabular}{|c|c|c|c|c|c|c|}
\hline $\begin{array}{l}\text { Varyansın Kaynağı Düşmanca } \\
\text { Cinsiyetçilik }\end{array}$ & KT & Sd & ко & F & $\mathrm{p}<$ & Fark \\
\hline Gruplararası & 9,372 & 2 & 4,686 & & & \\
\hline Gruplariçi & 493,399 & 543 & ,909 & 5,157 & 006 & IIÇe- \\
\hline Toplam & 502,771 & 545 & & & & II/Merkez Ilçe \\
\hline $\begin{array}{l}\text { Varyansın Kaynağı Korumacı } \\
\text { Cinsiyetçilik }\end{array}$ & KT & Sd & KO & F & $\mathrm{p}<$ & Fark \\
\hline Gruplararası & 3,664 & 2 & 1,832 & & & \\
\hline Gruplariçi & 412,537 & 543 & ,760 & 2,411 & ,091 & - \\
\hline Toplam & 416,200 & 545 & & & & \\
\hline
\end{tabular}

Fakat eta kare değeri ,01 olup oldukça küçük bir etki olduğu söylenebilir. Öğretmen adaylarının korumacı cinsiyetçi tutumlarında ise gruplar arasında anlamlı bir fark yoktur $(\mathrm{p}<, 091)$.

Öğretmen adaylarının anne eğitim durumlarına göre cinsiyetçi tutumlarındaki farkları ortaya koymak için yapılan ANOVA analizi sonuçları Tablo 6'da görülmektedir.

Tablo 6. Öğretmen adaylarının anne eğitim durumuna göre cinsiyetçi tutumlar ANOVA

\begin{tabular}{|c|c|c|c|c|c|c|c|}
\hline $\begin{array}{l}\text { Varyansın Kay- } \\
\text { nağı Düşmanca } \\
\text { Cinsiyetçilik }\end{array}$ & KT & Sd & КО & $\mathbf{F}$ & $\mathrm{p}<$ & Fark & \\
\hline $\begin{array}{l}\text { Gruplararası } \\
\text { Gruplariçi } \\
\text { Toplam }\end{array}$ & $\begin{array}{l}17,093 \\
489,300 \\
506,393\end{array}$ & $\begin{array}{l}3 \\
546 \\
549\end{array}$ & $\begin{array}{l}5,698 \\
, 896\end{array}$ & 6,358 & ,000 & \multicolumn{2}{|c|}{$\begin{array}{l}\text { Herhangi bir okul mezunu } \\
\text { olmayan-önlisans + } \\
\text { İlkokul ya da ortaokul } \\
\text { mezunu- önlisans + } \\
\text { Lise veya dengi okul } \\
\text { mezunu- önlisans+ }\end{array}$} \\
\hline $\begin{array}{l}\text { Varyansın Kay- } \\
\text { nağı Korumaci } \\
\text { Cinsiyetçilik }\end{array}$ & KT & Sd & & KO & $\mathbf{F}$ & $\mathrm{p}<$ & Fark \\
\hline Gruplararası & 2,956 & 3 & & ,985 & & & \\
\hline Gruplariçi & 418,013 & 546 & & ,766 & 1,287 & ,278 & - \\
\hline Toplam & 420,969 & 549 & & & & & \\
\hline
\end{tabular}


Anne ve baba eğitim durumu değişkeni dört grupta toplanmıştır. Bunlar; herhangi bir okul mezunu olmayan, ilkokul veya ortaokul mezunu, lise mezunu ve ön lisans-lisans-lisansüstü mezunu şeklindedir. Düşmanca cinsiyetçilik için yapılan testin sonuçlarına göre; öğretmen adaylarının anne eğitim durumuna göre düşmanca cinsiyetçi tutumlarında anlamlı bir fark vardır $(\mathrm{p}<, 000)$. Levene Testi sonucu sig değeri ,05 in altında olduğu için varyans eşteşliği sağlanamamış dolayısı ile izleme testi olarak Tamhane testi seçilmiştir $(\mathrm{p}=, 017)$. Tamhane izleme testi sonuçlarında görüldüğü gibi Önlisans/lisans/yüksek lisans/doktora mezunu olan annelerin çocuklarının anlamlı bir şekilde daha az düşmanca cinsiyetçi tutuma sahip oldukları tespit edilmiştir. Tüm gruplara göre değerlendirildiğinde herhangi bir okul mezunu olmayan, ilkokul veya ortaokul mezunu olan, lise veya dengi okul mezunu olan annelerin çocukları anlamlı bir şekilde Önlisans/lisans/yüksek lisans/doktora mezunu olan annelerin çocuklarına göre daha yüksek düzeyde düşmanca cinsiyetçi tutumları olduğu görülmüştür. Bu analizin eta kare değeri ,03 olup küçük bir etki olduğunu göstermektedir. Korumacı cinsiyetçilik boyutunda ANOVA sonuçlarına bakıldığında ise gruplar arasında anlamlı bir fark olmadığı görülmektedir $(\mathrm{p}<, 278)$. Dolayısı ile öğretmen adaylarının korumacı cinsiyetçi tutumlarında annelerinin eğitim durumlarına göre anlamlı bir fark yoktur.

Baba eğitim durumlarına göre öğretmen adaylarının cinsiyetçi tutumlarının ANOVA analizleri Tablo 7' de görülmektedir.

Tablo 7. Öğretmen adaylarının baba eğitim durumuna göre cinsiyetçi tutumlan ANOVA

\begin{tabular}{|c|c|c|c|c|c|}
\hline $\begin{array}{l}\text { Varyansın Kaynağı Düş- } \\
\text { manca Cinsiyetçilik }\end{array}$ & KT & Sd & КO & $\mathbf{F}$ & $\mathrm{p}<$ \\
\hline Gruplararası & 4,309 & 3 & 1,436 & & \\
\hline Gruplariçi & 502,083 & 546 & ,920 & 1,562 & 198 \\
\hline Toplam & 506,393 & 549 & & & \\
\hline $\begin{array}{l}\text { Varyansın Kaynağı Koru- } \\
\text { macı Cinsiyetçilik }\end{array}$ & KT & Sd & KO & $\mathbf{F}$ & $\mathrm{p}<$ \\
\hline Gruplararası & 795 & 3 & ,265 & & \\
\hline Gruplariçi & 420,174 & 546 & 770 & 344 & 793 \\
\hline Toplam & 420,969 & 549 & & & \\
\hline
\end{tabular}


Öğretmen adaylarının baba eğitim durumu ve düşmanca cinsiyetçi tutumları ile yapılan ANOVA sonuçları gruplar arasında anlamlı bir fark olmadığını göstermektedir $(\mathrm{p}<, 198)$. Benzer şekilde baba eğitim durumuna göre öğretmen adaylarının korumacı cinsiyetçi tutumlarında da anlamlı bir fark yoktur $(\mathrm{p}<, 793)$.

Aile çalışma durumlarına göre yapılan analizler ise Tablo 8'de özetlenmektedir.

Tablo 8. Aile çalışma durumlarına göre cinsiyetçi tutumları ANOVA

\begin{tabular}{|c|c|c|c|c|c|}
\hline $\begin{array}{l}\text { Varyansın Kaynağı Düş- } \\
\text { manca Cinsiyetçilik }\end{array}$ & KT & Sd & KO & F & $\mathrm{p}<$ \\
\hline Gruplararası & 789 & 2 & ,394 & & \\
\hline Gruplariçi & 501,129 & 539 & 930 & ,424 & 655 \\
\hline Toplam & 501,917 & 541 & & & \\
\hline $\begin{array}{l}\text { Varyansın Kaynağı Koruma- } \\
\text { cı Cinsiyetçilik }\end{array}$ & KT & Sd & KO & F & $\mathrm{p}<$ \\
\hline Gruplararası & 2,294 & 2 & 1,147 & & \\
\hline Gruplariçi & 414,772 & 539 &, 770 & 1,490 & ,226 \\
\hline Toplam & 417,066 & 541 & & & \\
\hline
\end{tabular}

Aile çalışma durumu değişkenine ait olan alt kategoriler iki ebeveynin de çalıştığı, iki ebeveynin de çalışmadığı ve anne veya babadan birinin çalıştı̆̆ 1 şeklinde oluşturulmuştur. Burada cinsiyetçilik açısından bir diğer önemli bulgu annelerin çalışma durumlarıdır. Öğretmen adaylarının sadece 16'sının annesi çalışmaktadır. Bu yüzden sadece anne çalışma durumları ile herhangi bir test yürütülememiştir. Tablo 8 'de görüldüğü üzere öğretmen adaylarının düşmanca veya korumacı cinsiyetçi tutumlarında ailelerin çalışma durumlarına göre anlamlı bir fark görülmemektir $(\mathrm{p}<, 655 ; \mathrm{p}<, 226)$.

Öğretmen adaylarının ailelerinin ekonomik gelir düzeylerine göre düşmanca cinsiyetçi tutumları arasında yapılan analiz Tablo 9'da görülmektedir.

Öğretmen adaylarından kendi algılarına göre ailelerinin ekonomik düzeylerini seçmeleri istenmiştir. Ekonomik gelir düzeyi düşük gelir, orta gelir ve yüksek gelir olarak formda yer almıştır. Yapılan analiz sonucunda öğretmen adaylarının algıladıkları ekonomik duruma göre düşmanca cinsiyetçi tutumlarında anlamlı bir fark olduğu görülmektedir $(p<, 009)$. Varyans eşteşliği için $(p<, 223)$ bir sonraki aşamada hangi grup- 
lar arasında anlamlı bir fark olduğunu görmek adına izleme testlerinden Scheffe testi seçilmiştir. Scheffe testine göre; öğretmen adaylarından ailelerinin ekonomik durumunu düşük belirtenler ile orta düzeyde belirtenler arasında düşmanca cinsiyetçilik açısından anlamlı bir fark vardır. Ekonomik durumunu düşük belirten öğretmen adaylarının düşmanca cinsiyetçi tutumları orta gelir düzeyi belirten öğretmen adaylarından anlamlı bir şekilde daha yüksektir. Fakat bu etkinin değeri ,02 olup oldukça küçük bir etkiye sahiptir. Buna ek olarak, algılanan ekonomik gelir düzeyi ile korumacı cinsiyetçilik tutumları arasında anlamlı bir fark yoktur.

Tablo 9. Ailelerin ekonomik gelir düzeylerine göre cinsiyetçi tutumlarn ANOVA tablosu

\begin{tabular}{|c|c|c|c|c|c|c|}
\hline $\begin{array}{l}\text { Varyansın Kaynağı } \\
\text { Düşmanca Cinsiyetçilik }\end{array}$ & KT & $\mathrm{Sd}$ & KO & $\mathbf{F}$ & $\mathrm{p}<$ & Fark \\
\hline Gruplararası & 8,731 & 2 & 4,366 & & & \multirow{3}{*}{$\begin{array}{l}\text { Düşük- } \\
\text { orta gelir }\end{array}$} \\
\hline Gruplariçi & 497,661 & 547 & ,910 & 4,798 & ,009 & \\
\hline Toplam & 506,393 & 549 & & & & \\
\hline $\begin{array}{l}\text { Varyansın Kaynağı } \\
\text { Korumacı Cinsiyetçilik }\end{array}$ & KT & Sd & KO & $\mathbf{F}$ & $\mathrm{p}<$ & Fark \\
\hline Gruplararası & 2,980 & 2 & 1,490 & & & \\
\hline Gruplariçi & 417,988 & 547 & 764 & 1,950 & 143 & - \\
\hline Toplam & 420,969 & 549 & & & & \\
\hline
\end{tabular}

Öğretmen adaylarının toplumsal farklılıklara yönelik ders/seminer/çalıştaya katılma durumlarına göre düşmanca ve korumacı cinsiyetçi tutumlarında farklılık olup olmadığını anlamak için yapılan bağımsız örneklemler t-testi Tablo 10'da görülmektedir.

Tablo 10. Öğretmen adaylarının seminere katılma durumlarnna göre cinsiyetçi tutumlarn t-testleri

\begin{tabular}{|c|c|c|c|c|c|c|}
\hline Grup & $\mathbf{n}$ & $\mathrm{X}$ & ss & Sd & $t$ & $\mathrm{p}<$ \\
\hline \multicolumn{7}{|c|}{ Düşmanca Cinsiyetçilik } \\
\hline Evet & 109 & 3,40 & ,92527 & \multirow{2}{*}{548} & \multirow{2}{*}{1,190} & \multirow{2}{*}{,236 } \\
\hline Hayır & 441 & 3,53 & 1,08914 & & & \\
\hline \multicolumn{7}{|c|}{ Korumacı Cinsiyetçilik } \\
\hline Evet & 109 & 3,63 & 83670 & \multirow{2}{*}{548} & \multirow{2}{*}{2,394} & \multirow{2}{*}{,018 } \\
\hline Hayır & 441 & 3,88 & ,99800 & & & \\
\hline
\end{tabular}


Toplam 109 öğretmen adayı toplumsal farklılıklar konusunda seminer veya çalıştay gibi çalışmalara katılım göstermişken 441 öğretmen adayının herhangi bir çalışmaya katılmadığı Tablo 10 'da görülmektedir. Öğretmen adaylarının herhangi bir ders/seminer/çalıştaya katılma durumuna göre düşmanca cinsiyetçi tutumlarında anlamlı bir fark yoktur $(\mathrm{p}<, 236)$. Fakat öğretmen adaylarından çalışmalara katılım gösterenlerin korumacı cinsiyetçi tutumu katılmayanlara göre anlamlı derecede daha düşüktür $(\mathrm{p}<, 018)$. T testinin eta kare değeri ,01 olduğu tespit edilmiş ve oldukça küçük bir etkiyi göstermektedir.

Son olarak, öğretmen adaylarının doğdukları illere ilişkin verdikleri bilgiler ile 2015 yılından önceki yerel seçim sonuçları birleştirilerek yeni bir değişken elde edilmiştir. Öğretmen adaylarının doğdukları ildeki belediyelerin seçim sonuçları, partilerin fikri yönelimleri ve siyasi söylemleri temel alınarak sosyal demokrat ve muhafazakâr partiler şeklinde iki grupta değerlendirilmiştir. Siyaset geleneğinde merkez sağ, İslami motifler ve milliyetçilik şeklinde üç ana özelliğe sahip partiler muhafazakâr kategorisinde sınıflandırılmıştır (Suveren, 2014).

Tablo 11. Yerel seçim sonuçlarnna göre cinsiyetçi tutumları t testleri

\begin{tabular}{|c|c|c|c|c|c|c|}
\hline Grup & $\mathrm{n}$ & $X$ & ss & Sd & $t$ & $\mathrm{p}<$ \\
\hline \multicolumn{7}{|l|}{$\begin{array}{l}\text { Düsşmanca Cin- } \\
\text { siyetçilik }\end{array}$} \\
\hline Sosyal Demokrat & 209 & 3,38 & ,93483 & \multirow{2}{*}{534} & \multirow{2}{*}{2,513} & \multirow{2}{*}{,012 } \\
\hline Muhafazakâr & 327 & 3,60 & ,96691 & & & \\
\hline \multicolumn{7}{|l|}{$\begin{array}{l}\text { Korumacı Cinsi- } \\
\text { yetçilik }\end{array}$} \\
\hline Sosyal Demokrat & 209 & 3,84 & ,84107 & & -108 & 914 \\
\hline Muhafazakâr & 327 & 3,84 & ,90619 & 534 &,- 108 & ,914 \\
\hline
\end{tabular}

Sosyal demokrat parti kategorisi ise iç tüzüklerinde "özgürlük, eşitlik, dayanışma, barış, emeğin yüceliği, hukukun üstünlüğü, dengeli kalkınma, refah" gibi sosyal demokrasinin kavramlarına vurgu yapılan partilerden oluşturulmuştur (Önkaş, 2006). Bu şekilde, sosyal demokrat kategorisine Cumhuriyet Halk Partisi, Barış ve Demokrasi Partisi; bağımsız adayların hâkim olduğu illerde doğanlar ve yurtdışında doğanlar dâhil edilmiştir. Muhafazakâr parti kategorisine ise Milliyetçi Hareket Partisi ve Adalet ve Kalkınma Partisinin hâkim olduğu illerde doğanlar dâhil edilmiştir. Bu şekilde, öğretmen adaylarının doğup yaşadıkları iller, 
hâkim olan siyasi görüşe göre iki kategoriye ayrılarak ortaya çıarılmıştır. Öğretmen adaylarının doğdukları ilin seçim sonuçlarına göre cinsiyetçi tutumlarında anlamlı bir fark olup olmadığı incelenmiştir.

Tabloda görüldüğü üzere öğretmen adaylarının doğdukları şehirlerde hâkim olan siyasi görüşe göre düşmanca cinsiyetçi tutumlarında anlamlı bir fark vardır $(\mathrm{p}<, 012)$. Muhafazakâr yerel yönetimlerin olduğu şehirlerden gelen öğretmen adaylarının, diğer gruba göre anlamlı bir şekilde daha yüksek düşmanca cinsiyetçi tutumlar gösterdiği görülmektedir. Bu testin eta kare değeri ,01 ile oldukça küçük bir etkiyi ortaya koymaktadır. Bununla birlikte korumacı cinsiyetçi tutumlar için gruplar arasinda anlamlı bir fark yoktur $(\mathrm{p}<, 914)$.

\section{Tartışma ve Sonuç}

Bu araştırmada erken çocukluk dönemi bağlamında geleceğin öğretmenlerinin oldukça yüksek olarak değerlendirebilecek cinsiyetçi tutumlara sahip olduğu belirlenmiştir. Okul öncesi ve sınıf öğretmenliği programlarına devam eden öğretmen adaylarının tutumları genel olarak değerlendirildiğinde ortalamanın üzerinde çelişik duygulu cinsiyetçi tutumlar göstermektedirler. Erkek öğretmen adaylarının belirgin bir şekilde kadın öğretmen adaylarına göre daha yüksek düşmanca cinsiyetçi tutumlara sahip oldukları görülmüştür. Bu sonuç cinsiyetler arasındaki tutum farklarına yönelik bulgular içeren birçok araştırma ile paraleldir (Allen ve diğ., 2009; Alptekin, 2014; Ayan, 2014; Erkurt, 2015; Glick ve diğ, 2016; Güçlü Ergin, 2008; Yumuşak; 2013). Kadınların erkeklere göre korumac1 cinsiyetçi tutumlarının daha yüksek olduğunu gösteren bazı araştırmalara karşın (Allen ve diğ., 2008; Alptekin, 2014; Ayan, 2014; Erkurt, 2015; Güçlü Ergin, 2008; Yumuşak, 2013), bu çalışmada korumacı cinsiyetçilik bağlamında gözlenen farklar istatistiksel olarak anlamlı bulunmamıştır.

Alanyazında eğitim düzeyinin düşüklügüünün hem korumacı cinsiyetçiliği hem de düşmanca cinsiyetçiliği yordadığına dair çalışmalar mevcuttur (Hellmer ve dĭg, 2018). Bu çalışmada yükseköğretime devam eden bireylerin ebeveynlerinin eğitim durumlarına bakılmış; anneleri yükseköğretim kurumlarından mezun olan öğretmen adaylarının düşmanca cinsiyetçi tutumlarının diğer gruplardan anlamlı düzeyde daha düşük olduğu görülmüş̧ür. Erkurt (2015) yaptığı çalışmada anne eğitim 
durumunun evlilikte kadına uygulanan şiddeti negatif yönde yordadığını ortaya koymuştur. Doğrudan düşmanca cinsiyetçi tutumlarla da ilişkilendirilebilecek bu durum anne eğitiminin önemini vurgulamaktadır. Nitekim annelerin eğitim durumuna göre cinsiyetçi tutumlarda gözlenen farkın babaların eğitim durumuna göre gözlenmemesi yine doğrudan cinsiyetçi tutumlar ile ilişkilidir. Çocuk yetiştirmenin tüm yükünün annelerin üzerinde olduğu toplumumuzda annelerin eğitim düzeyi ve deneyimleri doğrudan çocukları üzerinde bir etki yaratırken babalar için aynı durumun söz konusu olmadığı düşünülebilir. Kuzlak, Savaş ve Sakallı-Uğurlu (2017) yaptıkları çalışmada, çalışmaya katılan kadınların annelerinin eğitim seviyesi yükseldikçe, cinsiyetçi tutumlarının ve muhafazakârlık düzeylerinin azaldığını ortaya koymuştur. Buna ek olarak, erkeklerin annelerinin eğitim seviyesi yükseldikçe, kadınlara benzer şekilde, cinsiyetçi tutumlarının azaldığı görülmektedir.

Öğretmen adaylarının doğdukları yerleşim türüne bakıldığında il ya da merkez ilçede doğanların, ilçede doğan öğretmen adaylarına göre anlamlı bir şekilde daha düşük düzeyde düşmanca cinsiyetçi tutumlara sahip oldukları görülmektedir. Bu durumun büyük yerleşim yerlerinde toplumsal çeşitliliğin ve uyaranların daha fazla olması, eğitim seviyesinin daha yüksek olması gibi sebeplerden kaynaklandığı düşünülebilir. Fakat öğretmen adaylarının korumacı cinsiyetçi tutumlarında yerleşim türüne göre anlamlı bir fark yoktur. Özdemir (2017) de çalışmasında benzer şekilde öğretmen adaylarının korumacı cinsiyetçi tutumlarında yerleşim türüne göre bir fark olmadığını ortaya koymuştur. Fakat ilde yaşayanların diğer gruplara göre düşmanca cinsiyetçi tutumlarının daha yüksek olduğunu vurgulamıştır.

$\mathrm{Bu}$ araştırmada öğretmen adaylarının ailelerinin ekonomik durumuna göre düşük ve orta gelirli olmalarıyla düşmanca cinsiyetçi tutumları açısından anlamlı bir fark olduğu bulunmuştur. Düşük gelirli ailelerden gelen öğretmen adayları orta gelirli ailelerden gelenlere göre anlamlı bir şekilde daha yüksek düşmanca cinsiyetçi tutumlara sahiptir. Yapılan bazı araştırmalar da ekonomik gelir düzeyinin toplumsal cinsiyet alg1sinda farklılıklar yarattı̆̆ını; gelir düzeyinin artması ile daha olumlu bir etki oluştuğunu göstermektedir (Altıntaş ve Altınova 2015; Kodan, 2013). Ekonomik durumun iyi olması aynı zamanda sahip olunan olanaklar ve 
eğitim ile de doğrudan ilişkili olduğu için düşmanca cinsiyetçi tutum açısından fark yarattığı düşünülebilir.

Öğretmen adaylarının okudukları sınıflara göre korumacı cinsiyetçi tutumlarında anlamlı bir fark olduğu ortaya çıkmıştır. Bu bağlamda 4 . sinıfta olan öğretmen adayları diğer tüm sınıflardaki öğretmen adaylarına göre anlamlı bir şekilde daha düşük korumacı cinsiyetçi tutumlar göstermektedirler. Benzer şekilde öğretmen adaylarının yaşları arttıkça korumacı cinsiyetçiliğin azaldığı görülmektedir. Yaş ve korumacı cinsiyetçilik arasında negatif yönlü bir ilişki söz konusudur. Toplumsal cinsiyet algısı ile ilgili yapılan bazı çalışmalarda ise üniversite okuyan öğrencilerde yaş ve sınıf değişkeni açısından anlamlı bir fark bulunamamıştır (Atış, 2010; Güzel, 2016; Pınar, Taşkın ve Eroğlu; 2008). Fakat üniversitede okuyan ve gün geçtikçe deneyimleri artan öğrencilerin kendi bağımsızlıklarını kazanma yolunda ilerlemeleri, korumacı cinsiyetçi tutumlar açısından fark oluşmasına sebep olabilir. Kadınların eğitimli olması, ekonomik özgürlüklerini kazanmak için çaba gösteriyor olmaları gibi sebeplerden dolayı korumacı cinsiyetçi tutumlarının azaldığı düşünülebilir. Aynı zamanda ailelerinden uzakta yaşam deneyimleri kazanan öğretmen adayları için korumacı cinsiyetçiliğin azaldığı düşünülebilir. Alanyazınla çelişen bu sonuçlar araştırmada elde edilen bir diğer sonuç ile desteklenmektedir. Diğer bir deyişle, öğretmen adaylarının daha önce toplumsal farklılıklar konusunda herhangi bir ders, seminer veya çalıştaya katılmış olmaları korumacı cinsiyetçi tutumlarında anlamlı bir farka işaret etmiştir. Herhangi bir ders, seminer veya çalıştaya katılan öğretmen adayları katılmayan öğretmen adaylarına göre daha az korumacı cinsiyetçi tutumlara sahiptir.

Korumacı cinsiyetçi tutumlarında öğretmen adaylarının, aile çalışma durumuna göre anlamlı bir fark görülmemektedir. Buna paralel olarak Atış (2010) hemşirelik öğrencileri ile yaptığı çalışmada, annelerin çalışma durumunun toplumsal cinsiyet rolü tutumları açısından anlamlı bir fark yaratmadığını ortaya koymuştur. Başka bir araştırmada ise öğrencilerin toplumsal cinsiyet rollerine yönelik bakış açıları ile babaların çalışma durumu arasındaki ilişkiye işaret edilmiştir. Güzel (2016) tarafından yapılan bu araştırmada babası emekli olan öğrencilerin toplumsal cinsiyet rolleri konusundaki eşitlikçi bakış açısının, babası halen çalışanlara göre daha fazla olduğu sonucuna ulaşmıştır. 
Bu çalışmada muhafazakâr partilerin hâkim olduğu yerlerde doğmuş öğretmen adaylarının sosyal demokrat partilerin hakim olduğu yerlerde doğanlara göre düşmanca cinsiyetçi tutumlarının daha yüksek olduğu ortaya koyulmuştur. Benzer şekilde, Lye ve Waldron (1997) yaptıkları çalışmada muhafazakâr politik inançların geleneksel cinsiyet rolleri ile ilişkisi olduğunu ortaya koymuştur. Christopher ve Mull (2006) tarafından yapılan araştırmada da benzer şekilde muhafazakâr ideolojinin çelişik cinsiyetçiliğin bazı boyutlarını yordadığı bulunmuştur. Bu bulgular, Akın (2015)'ın çalışmasında vurguladığı sonuçlarla benzerlik göstermektedir. Bu çalışmaya göre, 2011 yılı seçimlerinde AKP ve CHP'nin kadın hakkındaki siyasal reklam, söylem ve imgeleri incelendiğinde, AKP'nin söylemlerinde geleneksel kadın kimliğinin yansıtıldığı, CHP'nin ise kadın hakları ve sorunlarını, kadın ve erkek eşitliği vurgusu ile modern kadın kimliğini öne çıardığı görülmektedir (Akın, 2015).

Sonuç olarak cinsiyetçilik düşmanca veya korumacı olsun bireylerin tutumlarında belirgin bir şekilde ortaya çıkan olumsuz bir olgudur. Bunun birçok sebebi olduğu söylenebilir. Özellikle erken çocukluk bağlamında yapılan araştırmalara bakıldığında erken yaşlarda çocukların maruz kaldıkları materyallerde cinsiyet kalıp yargılarını pekiştiren araçların kullanıldığı görülmektedir (Köseler, 2009; Sezer, 2010; Tezer Asan, 2010). Erken çocukluk dönemi öğretmen adaylarının ve öğretmenlerinin, bu kritik gelişim döneminde kalıp yargıların gelişmesini engellemek için daha dikkatli olması gerekmektedir. Fakat öğretmen adaylarının bu kalıp yargıları içselleştirmiş oldukları çeşitli araştırmaların sonuçlarında görülmektedir (Aslan 2015; Polat, 2010). Bununla birlikte, hali hazırda görev yapan öğretmenlerin cinsiyetçi kalıp yargılarının olması cinsiyetçilik bağlamında olumsuz sonuçlar doğurmaktadır (Polat, 2010; Söylemez, 2010; Tezer Asan, 2010).

$\mathrm{Bu}$ çalışma ile öğretmen adaylarının cinsiyetçi tutumları konusunda bir durum tespiti yapılmış ve toplumsal farklılıklarla ilgili bir seminere katılmanın ufak da olsa farklar yaratabileceği görülmüştür. Bu açıdan erken çocukluk döneminde çocuklarla çalışacak öğretmenlerin eğitiminde önlemler alınması önerilebilir. Öğretmen adaylarının cinsiyet ayrımc1lığ1 ve çeşitli toplumsal farklılıklar konularında farkındalıklarını artırmak amacıyla eğitim programları düzenlenebilir. Gelecek araştırmalarda öncelikli olarak sistem içinde görev yapan öğretmenlerin cinsiyetçi tu- 
tumlarının belirlenmesi kalıcı değişimler yaratmak adına önemli bir ihtiyaç olarak görülmektedir. Nitekim bu araştırmanın planlama aşamasında önce okullarda çalışan öğretmenlerin tutumları belirlenmek istenmiş ancak araştırmanın yürütüleceği ilde Milli Eğitim Müdürlüğünden gerekli izinler ne yazık ki alınamamıştır. Bu durum, öğretmenlerin tutumlarının önemi ve cinsiyetçilik konusunda resmî kurumların da duyarlılığının artırılmasına ihtiyaç olduğunu göstermektedir. Bu açıdan karar alma yetkisi olan resmî kurumların farklı çalışanları ile cinsiyetçi tutumların araştırılması alanyazına önemli bir katkı sağlayabilir.

Annelerin eğitim durumunun çocukların tutumlarına etkisi düşünüldüğünde eğitim alma imkânı olmayan anneler için cinsiyet eşitliğine yönelik eğitimler düzenlenmesi de önemli görülmektedir. Sivil toplum kuruluşları aracılığı ile anne eğitim programlarında cinsiyetçilik ve toplumsal cinsiyet rolleri konularına yer verilebilir. Küçük yerleşim yerlerinde özellikle kadınların güçlenmesini destekleyen sivil toplum kuruluşları ile yerel halkın farkındalığını artırmaya yönelik etkinlikler, çalışma ve eğitimler planlanması da cinsiyetçilikle mücadele etmeye zemin hazırlayabilir. Eğitimlerin/çalışmalara katılmanın öğretmen adaylarının tutumları üzerinde yarattığı fark değerlendirildiğinde üniversitelerde cinsiyet eşitliği konusunda derslerin arttırılması ya da genel kültür dersleri ile bu konuların bütünleştirilmesi önerilebilir.

$\mathrm{Bu}$ çalışmanın bulguları düşük etki büyüklükleri ışığında ve katılımcıların ulaşılabilir örnekleme ile belirlendiği dikkate alınarak değerlendirilmelidir. Benzer çalışmaların farklı şehirlerde tesadüfi örnekleme ile belirlenen katılımcılarla ve daha ileri düzey istatistiksel analizlerle tekrar edilmesi etki büyüklüğü yüksek ve genellenebilir sonuçlara ulaşılmasını sağlayabilir. Çalışmanın sınırlılıkları arasında ise araştırmada erkek öğretmen adaylarının sayısının düşük olması gösterilebilir. Yeni araştırmalarda daha fazla sayıda erkek öğretmen adayına ulaşılarak cinsiyetçilik konusunda alanyazına farklı bir bakış açısı sunulabilir. Son olarak, bu çalışmada öğretmen adaylarının yetiştikleri illerdeki hâkim siyasi görüş, dolaylı yollardan belirlenen bir değişken olup eğitim araştırmac1ları gelecek araştırmalarda siyasal bilgiler ve sosyoloji gibi alanlardan araştırmacılarla işbirliği yaparak eğitimcilerin siyasi görüşleri temelinde cinsiyetçi tutumlarını araştırabilir. 


\title{
EXTENDED ABSTRACT
}

\section{Sexist Attitudes of Future Teachers in the Context of the Early Childhood Period}

\author{
* \\ İlayda Kimzan - Arzu Arıkan \\ Muğla Sttkı Koçman University-Anadolu University
}

Starting with the moment that individuals become a member of a society and culture, they encounter the gender roles that emphasizes the differences between the sexes. Especially in cultures where patriarchal values are dominant, gender roles present itself strongly in daily life which bring along discrimination and sexism. In this context, this study aims to focus on sexism in teacher training and investigates the sexist attitudes of the early childhood teacher candidates, namely the candidates preparing to become preschool and primary school teachers. Since the majority of the pre- and primary school teacher candidates are women, studies focusing on sexism in these areas may provide solutions. In this context, the degree of sexist attitudes of early childhood teacher candidates and the degree of differences in these attitudes based on demographic characteristics are described using a correlational research design in this study. The participants consist of 550 teacher candidates who were selected with convenient sampling method from different classes of preand primary school bachelor programs of a state university. The Ambivalent Sexism Inventory developed by Glick and Fiske (1996) and adapted to Turkish by Sakalli-Uğurlu (2002) was used in the study to measure the sexist attitudes of teacher candidates. All the required permissions for this study are granted by the University Ethics Review Board. The collected data meets the normality assumptions and therefore, parametric tests were used to analyze the data. Descriptive statistics, t-tests, ANOVA and Pearson Correlation were utilized as data analysis methods.

It is observed that teacher candidates have mid-level hostile sexist attitudes and above average benevolent sexist attitudes. The hostile sexist attitudes of male teacher candidates are higher in a significant level compared to female teacher candidates. There is no significant difference 
between males and females in terms of benevolent sexism and its subdimension heterosexual intimacy. While in the supplementary differentiation between complementary gender differentiation sub-dimension, females' average is significantly higher than males, in the protective paternalism sub-dimension, males have significantly higher levels of this attitude.

There is no significant difference in the analysis made for teacher candidates' hostile sexist attitudes, grades, ages, family occupation status and participation in lectures/seminars/workshops. In addition to these, there is also no significant difference between hostile sexist attitudes and settlement type. However, the follow-up tests shows that teacher candidates who were born in a district of a city have higher levels of hostile sexist attitudes compared to who were born in a city or central district of a city. The analysis based on mother education status reveals that teacher candidates, whose mothers have a(n) associate's/bachelor/graduate/doctorate degree, have significantly lower levels of hostile sexist attitudes. In contrast to these candidates, teacher candidates whose mothers are uneducated, primary, secondary, or high-school graduate, have higher levels of hostile sexist attitudes. There is a significant difference in terms of hostile sexist attitudes between the teacher candidates who state that their family has a low level financial status and who state that their family has mid-level financial status. Those candidates stated low level financial status for their family have significantly higher levels of hostile sexist attitudes compared to candidates stated mid-level financial status for their family. There is a significant difference in teachers' sexist attitudes based on the dominant political view of the city where the teacher candidates were born. In this regard, teacher candidates from the cities with conservative municipal administration show significantly higher levels of hostile sexist attitudes compared to the candidates from cities that have social democratic municipal administration.

The analysis for benevolent sexism shows that there is no significant difference based on the type of settlement born in, mother or father education status, family occupation status, perceived financial status and the dominant political view in the city born in. However, senior year teacher candidates have significantly less benevolent sexist attitudes compared to freshman, sophomore, and junior year teacher candidates. There is a 
significant and negative relationship between teacher candidates' ages and benevolent sexist attitudes. Therefore, as the candidates get older, the benevolent sexist attitudes decrease. It is also observed that teacher candidates, who participated in lectures/seminars/workshops for social differences, have significantly lower levels of benevolent sexist attitudes compared to candidates who did not participated in such activities.

As a result, either hostile or benevolent, sexism is a negative phenomenon which presents itself in individuals' attitudes and there can be many reasons underlying that attitudes. In the light of these results some precautions can be suggested for early childhood education. To better prepare future teachers, various education programs and courses may be offered on the topics of gender discrimination and social diversity. It may also be important to provide training programs on gender equality for mothers since the study shows that the educational status of the teacher candidates' mothers has an effect on the candidates' sexist attitudes. Still, these results should be evaluated by taking into consideration the low effect sizes and the use of convenient sampling in the study. Future studies, conducted in different cities using random sampling and utilizing more advanced statistical analysis may provide desired effect sizes and more generalizable results.

\section{Kaynakça / References}

Akbar, T., ve Azam, F. (2018). Gender issues in children's literature: An analysis of fairytales. Pakistan Journal of Education, 35(1), 59-70.

Akın, D. (2015). Siyasal reklamlarda kadın söylemi ve kadın imgeleri: 2011 genel seçimleri örneğinde akp ve chp televizyon siyasal reklamları üzerine bir inceleme. İletişim Kuram ve Araştırma Dergisi, 41, 277-289.

Allen, C. T., Swan, S. C., ve Raghavan, C. (2009). Gender symmetry, sexism, and intimate partner violence. Journal of Interpersonal Violence, 24(11), 1816-1834.

Alptekin, D. (2014). Çelişik duygularda toplumsal cinsiyet ayrımcılı̆̆ 1 sorgusu: Üniversite gençliğinin cinsiyet algısına dair bir araştırma. Selçuk Üniversitesi Sosyal Bilimler Enstitüsü Dergisi, 32, 203-211.

Altuntaş, O., ve Altınova, H., H. (2015). Toplumsal cinsiyet algısı ile sosyoekonomik değişkenler arasındaki ilişkinin belirlenmesi. Turkish Studies 10(6), 83-100. 
Aslan, G. (2015). Öğretmen adaylarının toplumsal cinsiyet algılarına ilişkin metaforik bir çözümleme. Eğitim ve Bilim, 40(181). 363-384.

Atış, F. (2010). Ebelik/Hemşirelik 1. ve 4. sınıf öğrencilerinin toplumsal cinsiyet rollerine ilişkin tutumlarının belirlenmesi. Yayımlanmamış Yüksek Lisans Tezi. Çukurova Üniversitesi, Adana.

Auspurg, K., Hinz, T., ve Sauer, C. (2017). Why should women get less? Evidence on the gender pay gap from multifactorial survey experiments. American Sociological Review, 82(1), 179-210.

Avcl, Ö. H., Karababa, A., ve Zencir, T. (2019). Toplumsal cinsiyet bağlamında erkek okul öncesi öğretmen adayları: Algıladıkları güçlükler ve gelecek kaygıları. Hacettepe Üniversitesi Ĕ̆itim Fakültesi Dergisi, 34(4), 1092-1106.

Ayan, S. (2014). Cinsiyetçilik: Çelişik duygulu cinsiyetçilik. Cumhuriyet Tıp Dergisi, 36, 147-156.

Balcı, E., ve Sel, B. (2017). İlkokul Türkçe ders kitaplarında yer alan çocuk edebiyatı ürünlerinde toplumsal cinsiyet eşitsizliğine ilişkin bir araştırma. Turkish Journal of Social Research/Turkiye Sosyal Araştıdrmalar Dergisi, 21(3), 723-740.

Bayhan, V. (2012). Beden sosyolojisi ve toplumsal cinsiyet. Doğu Batı Düşünce Dergisi, 63, 147-164.

Bayraktar, S., ve Güder, S. Y. (2019). Okul öncesi öğretmen adaylarının toplumsal cinsiyet rolüne ilişkin tutumları ile eleştirel düşünme eğilimleri ilişkisi. Anadolu Journal of Educational Sciences Internatio al, 9(2), 640-665.

Bee, H. and Boyd, D. (2009). Çocuk gelişim psikolojisi (Çev. Ed. O. Gündüz). İstanbul: Kaknüs Yayınları.

Berk, L. E. (2013). Bebekler ve çocuklar: Doğum öncesinden orta çocukluğa. (Çev. Işıkoğlu Erdoğan, N.). Ankara: Nobel. (2013).

Burn, S. M., ve Busso, J. (2005). Ambivalent sexism, scriptural literalism, and religiosity. Psychology of Women Quarterly, 29(4), 412-418.

Burt, M. R. (1980). Cultural myths and supports for rape. Journal of Personality and Social Psychology, 38, 217-230.

Büyüköztürk, Ş., Kılıç Çakmak, E., Akgün, Ö., Karadeniz, Ş., ve Demirel, F. (2008). Bilimsel araştırma yöntemleri. Ankara: Pegem A Yayıncılık.

Chancer, L. S., ve Watkins, B. X. (2013). Cinsiyet, ırk ve sınıf. (B. Uraz, Çev.) İstanbul: Babil Yayınları. 
Christopher, A. N., and Mull, M. S. (2006). Conservative ideology and ambivalent sexism. Psychology of Women Quarterly, 30(2), 223-230.

Coulter, R. P. (1995). Struggling with sexism: Experiences of feminist firstyear teachers. Gender and Education, 7(1), 33-50.

Cowie, L. J., Greaves, L. M., ve Sibley, C. G. (2019). Sexuality and sexism: Differences in ambivalent sexism across gender and sexual identity. Personality and Individual Differences, 148, 85-89.

Dilek, A. (2014). 4-6 yaş çocuk öykülerindeki kadın kahramanların mesleksel analizi. Journal of Aafqaz University, 2(1), 94-102.

Erden, F. (2004). Early childhood teachers' attitudes toward gender roles and toward discipline. Hacettepe Üniversitesi Ĕ̆itim Fakültesi Dergisi, 27, 83-90.

Erdol Acar, T., ve Gözütok, F. D. (2019). Toplumsal cinsiyet eşitliği eğitim programının değerlendirilmesi. Elementary Education Online, 18(4), 1497-1519.

Erdol, T. A., Özen, F., ve Toraman, Ç. (2019). Türkiye'deki eğitim fakültesi öğrencilerinin toplumsal cinsiyet eşitliğine yönelik görüşleri. Journal of Kirsehir Education Faculty, 20(2), 793-844.

Erkurt, A. (2015). Kadına yönelik şiddet: çelişik duygulu cinsiyetçilik, yetkecilik ve sosyal baskınlık yönelimi açısından bir inceleme. Yayımlanmamış yüksek lisans tezi. Ankara Üniversitesi Sağlık Bilimleri Enstitüsü. Ankara.

Fette, J. (2018). Gender in contemporary French children's literature: The role of talents hauts. Children's Literature Association Quarterly, 43(3), 285306.

Glick, P., Sakallı-Uğurlu, N., Akbaş, G., Orta, I. M., ve Ceylan, S. (2016). Why do women endorse honor beliefs? Ambivalent sexism and religiosity as predictors. Sex Roles, 75(11-12), 543-554.

Glick, P., ve Fiske, S. T. (1996). The ambivalent sexism inventory: differentiating hostile and benevolent sexism. Journal of Personality and Social Psychology, 70(3), 491.

Güçlü-Ergin, N. (2008). Evli ve boşanmış kişilerin evlilik uyumu ve cinsiyetçilik açısından karşılaştırılması. Yayınlanmamış Yüksek Lisans Tezi. Ankara Üniversitesi Sosyal Bilimler Enstitüsü. Ankara.

Güzel, A. (2016). Öğrencilerin toplumsal cinsiyet rolleri tutumları ve ilişkili faktörler. Gümüşhane Üniversitesi Să̆lık Bilimleri Dergisi, 5(4), 1-11. 
Haskan Avcı, Ö., Karababa, A., ve Zencir, T. (2019). Toplumsal cinsiyet bağlamında erkek okul öncesi öğretmen adayları: Algıladıkları güçlükler ve gelecek kaygıları. Hacettepe Üniversitesi Eğitim Fakültesi Dergisi, 34(4), 1092-1106.

Hellmer, K., Stenson, J. T., ve Jylhä, K. M. (2018). What's (not) underpinning ambivalent sexism?: Revisiting the roles of ideology, religiosity, personality, demographics, and men's facial hair in explaining hostile and benevolent sexism. Personality and Individual Differences, 122, 2937.

Huck, S., W. (2008). Reading statistics and research. New York: Addison Wesley Longman.

Karasar, N. (1999). Bilimsel araştırma yöntemleri (9. Baskı). Ankara: Nobel Yayınları.

Kimzan, İ. (2016). Erken çocukluk dönemi öğretmen adaylarının cinsiyetçilik ve çokkültürlü eğitime yönelik tutumları arasındaki ilişki (Yayımlanmamış Yüksek Lisans Tezi). Anadolu Üniversitesi, Eskişehir, Türkiye.

Kimzan, İ., ve Arıkan, A. (2018). Erken çocukluk dönemi öğretmen adaylarının çokkültürlü eğitime yönelik tutumlarının incelenmesi. İnönü Üniversitesi Ĕ̆itim Fakültesi Dergisi, 19(3), 670-686.

Kılıçoğlu, E. B. (2016). Ayla Kutlu'nun çocuk edebiyatı ürünlerinde toplumsal cinsiyet rolleri. Yayımlanmamış yüksek lisans tezi. Kırklareli Üniversitesi Sosyal Bilimler Enstitüsü. Kırklareli.

Kodan, S. (2013). Evli bireylerin evlilik kalitesi toplumsal cinsiyet rollerine ilişskin tutumlar ve yaşam doyumları arasındaki ilişkilerin incelenmesi. Yayımlanmamış Yüksek lisans tezi. Atatürk Üniversitesi, Erzurum.

Koyuncu Şahin, M., Esen Çoban, A., ve Korkmaz, A. (2018). Toplumsal cinsiyet eşitliği ve Türk eğitim sistemindeki yeri: Okul öncesi öğretmen adaylarinin gözünden. Uluslararası Bilimsel Araştırmalar Dergisi (IBAD), 3(2), 735-752.

Köseler, F. (2009). Okul öncesi öykü ve masal kitaplarında toplumsal cinsiyet olgusu. Yayımlanmamış yüksek lisans tezi. Adnan Menderes Üniversitesi Sosyal Bilimler Enstitüsü. Aydın.

Kuzlak, A., Çuvaş, B., ve Sakallı, N. (2017). Relationship between mother and father education and vocational statuses with college students sexism and conservatism. Nesne Psikoloji Dergisi, 5(9), 89-109. 
Lye, D. N., ve Waldron, I. (1997). Attitudes toward cohabitation, family, and gender roles: Relationships to values and political ideology. Sociological Perspectives, 40(2), 199-225.

McLaren S. (2019) Media, sexism and the patriarchal war System: Why media literacy matters to peace education. In D. Snauwaert (Ed). Exploring Betty A. Reardon's Perspective on Peace Education. Pioneers in Arts, Humanities, Science, Engineering, Practice (p.161-170). Springer, Cham

Mikołajczak, M., and Pietrzak, J. (2014). Ambivalent sexism and religion: Connected through values. Sex Roles, 70(9-10), 387-399.

Öngören, S. (2019). Öğretmen adaylarının toplumsal cinsiyet algılarına göre okul öncesi öğretmenliğine ilişkin görüşleri. OPUS Uluslararası Toplum Araştırmaları Dergisi, 11(18), 1773-1796.

Önkaş, H. (2006). 1980 sonrası Türkiye'de sosyal demokrasi: CHP örneği. Yayınlanmamış Yüksek Lisans Tezi Muğla Üniversitesi Sosyal Bilimler Enstitüsü. Muğla.

Özdemir, N. (2015). Sexism against woman prospective study on physical education teacher candidates. Uluslararası Hakemli Psikiyatri ve Psikoloji Araştırmaları Dergisi, 2(2), 1-9.

Pınar, G., Taşkın, L., ve Eroğlu, K. (2008). Başkent üniversitesi öğrenci yurdunda kalan gençlerin toplumsal cinsiyet rol kalıplarına ilişkin tutumları. Sağlık Bilimleri Fakültesi Hemşirelik Dergisi, 1, 47-57.

Polat, S. (2010). Eğitimde ve sınıf içi süreçlerde cinsiyetçi yaklaşımlar. Yayımlanmamış yüksek lisans tezi. İstanbul Üniversitesi Sosyal Bilimler Enstitüsü. İstanbul.

Sakallı-Uğurlu, N. (2002). Çelişik duygulu cinsiyetçilik ölçeği: Geçerlik ve güvenirlik çalışması. Türk Psikoloji Dergisi, 17(49), 47 - 58.

Sakallı-Uğurlu, N. (2003). Cinsiyetçilik: Kadınlara ve erkeklere ilişkin tutumlar ve çelişik duygulu cinsiyetçilik kuramı. Türk Psikoloji Yazıları, 6(11-12), 1-20.

Sarı, M. (2017). Türkiye'de cinsiyete dayalı ayrımcılığın kadının çalışma ve siyasal yaşamdaki yerine etkisi. Itobiad: Journal of the Human $\mathcal{E}$ Social Science Researches, 6(2), 1189-1203.

Sears, D.O., Peplau, A., ve Freedmann, J. (1988). Social pschology. PrenticeHall Inc. New Jersey.

Seçer, İ. (2013). SPSS ve LISREL ile pratik veri analizi: Analiz ve raporlaştırma. Ankara: Anı Yayıncilık. 
Sezer, M. Ö. (2010). Masallar ve toplumsal cinsiyet. İstanbul: Evrensel Basım Yayin.

Söylemez, A. S. (2010). Ders kitaplarında cinsiyetçilik: Illköğretim ve ortaöğretim Ingilizce ders kitaplarmdaki resimlerdeki cinsiyet temsilleri üzerine bir çaıı̧̧ma. Yayınlanmamış Doktora Tezi. Gazi Üniversitesi Eğitim Bilimleri Enstitüsü. Ankara.

Spears Brown, C., and Bigler, R. S. (2005). Children's perceptions of discrimination: A developmental model. Child development, 76(3), 533-553.

Suğur, S., ve Cangöz, İ. (2016). Üniversite yönetiminde kadınların eksik temsili üzerinde toplumsal cinsiyet ilişkilerinin rolü. Amme İdaresi Dergisi, 49(3), 89-115

Suveren, Y. (2014). Türkiye'deki sağ-muhafazakâr siyasetçilerin toplumsal ve kültürel eksenli muhafazakârlık algıları üzerine: bir alan çalışmasından notlar. Mülkiye Dergisi, 38(4), 5-40.

Şimşek, Ö. F. (2007). Yapısal eşitlik modellemesine giriş: Temel ilkeler ve LISREL uygulamaları. Ankara: Ekinoks.

Tabachnick, B. G., and Fidell, L. S. (2015). Using multivariate analysis. California State University Northridge: Harper Collins College Publishers.

Temiz, Z., ve Cin, F. M. (2017). Okul öncesi eğitimde cinsiyet eşitliği üzerine betimsel bir çalışma. Yüzüncü Yıl Üniversitesi Ĕ̆itim Fakültesi Dergisi, 14(1), 940-965.

Tezer Asan, H. (2010). Ders kitaplarında cinsiyetçilik ve öğretmenlerin cinsiyetçilik algilarının saptanması. Yayımlanmamış yüksek lisans tezi. Kocaeli Üniversitesi Sosyal Bilimler Enstitüsü. Kocaeli.

Yazıcl, F. ve Budak, F. (2017). The investigation of the students' attitudes toward identity differences in faculty of education. International Online Journal of Educational Sciences, 9(3), 879-896.

Yılmaz, S. (2016). Okul yöneticileri ve öğretmenlerin toplumsal cinsiyetçiliğge ve kadın yöneticilerin liderlik becerilerine yönelik görüşleri. Yayınlamış Doktora Tezi Anadolu Üniversitesi Eğitim Bilimleri Enstitüsü. Eskişehir.

Yumuşak, A. (2013). Üniversite öğrencilerinin flört şiddetine yönelik tutumları, toplumsal cinsiyetçilik ve narsisistik kişilik özellikleri arasındaki ilişki. Yayınlanmamış Yüksek Lisans Tezi. Gaziosmanpaşa Üniversitesi Eğitim Bilimleri Enstitüsü. Tokat.

Yuval-Davis, N. (2014). Cinsiyet ve millet (4). (A. Bektaş, Çev.) İstanbul: İletişim Yayınları. 


\section{Kaynakça Bilgisi / Citation Information}

Kimzan, İ. ve Arıkan, A. (2021). Erken çocukluk dönemi bağlamında geleceğin öğretmenlerinin cinsiyetçi tutumları. OPUSUluslararası Toplum Araştırmaları Dergisi, 18(39), 277-307. DOI: 10.26466/opus.831271. 